\title{
$\alpha$-BUNGAROTOXIN RECEPTORS ON NEURONS ISOLATED FROM TURTLE RETINA: MOLECULAR HETEROGENEITY OF BIPOLAR CELLS $^{1}$
}

\author{
WILLIAM M. JAMES ${ }^{2}$ AND WILLIAM L. KLEIN ${ }^{3}$ \\ Department of Neurobiology and Physiology, Northwestern University, Evanston, Illinois 60201
}

Received February 3, 1984; Revised July 26, 1984; Accepted August 8, 1984

\begin{abstract}
We studied localization of specific $\left.{ }^{125} \mathrm{I}\right]-\alpha$-bungarotoxin $(\alpha$-BTX) receptors on neurons dissociated from the adult turtle retina. Cells isolated from papain-treated retinas retained complex morphologies and were readily identifiable with cell classes (photoreceptors, Müller cells, multipolar and bipolar cells). Levels of $\alpha$-BTX receptors, measured by filtration assays, averaged $120 \mathrm{fmol} / \mathrm{mg}$ of protein whether or not retinas were treated with papain. Light microscope autoradiographs of isolated cells showed that only bipolar neurons had receptors for $\alpha$-BTX. In the presence of $d$-tubocurarine, no cells were labeled above background. Receptors were localized both close to and far from known sites of synaptic contacts. Highly labeled bipolar cells had grains over Landolt clubs, cell bodies, and axons as well as over dendrites, but lightly labeled cells had few grains over axons and cell bodies. Overall, most receptors occurred on dendrites, suggesting the activity of cellular mechanisms capable of directing receptor molecules to specific subcellular positions. The receptor phenotype was not expressed all or none, as autoradiographs of individual bipolar cells showed a wide spectrum of receptor levels. A maximum level of about 30,000 receptors/cell was seen. Unlabeled bipolar cells also were prevalent (70\%), and this group included virtually all "displaced" type bipolar cells. The data show molecular heterogeneity both between and within retina cell classes.
\end{abstract}

Cell surface molecules play a major role in neural function (Barondes, 1976; Stevens, 1979). Consequently, an important aspect of cellular neurobiology is to learn more about the nature of cell surface differentiation (McKay et al., 1981). Of particular interest is the selective incorporation into membranes of appropriate neurotransmitter receptors.

We recently have shown that highly arborized CNS neurons can be isolated and used for autoradiographic investigation of receptor molecules (James and Klein, 1982). This approach allows the identification of cell types that express specific receptor molecules and the localization of those molecules over segmental portions of a single identified neuron. We have used this approach in the current study to localize $\alpha$-bungarotoxin $\left(\alpha-B^{\prime} I^{\prime} X\right)$ receptors on recognizable cell types obtained from the adult turtle retina. The high affinity and specific activity of this toxin make it especially suitable for autoradiographic studies, and the persistence of $\alpha$-toxin receptor binding after a mild proteolytic step (Bartfeld and Fuchs, 1979; Klymkowsky et al. 1980; Lindstrom et al. 1980; Wenogle et al. 1981) allows for receptors to be labeled after cells have been prepared for isolation.

${ }^{1}$ This work was supported by a grant from the Illinois Cancer Society and by National Institutes of Health Grant DA02950 to W. L. K. We wish to thank Helga Kolb for her helpful comments and Vicki James for her expert technical assistance.

${ }^{2}$ Present address: Department of Physiology, Yale University, New Haven, CT 06510.

${ }^{3}$ To whom reprint requests should be sent.
$\alpha$-BTX has been used as a probe for nicotinic acetylcholine $(\mathrm{ACh})$ receptors in both central and peripheral neurons (reviewed in Morley and Kemp, 1981; Oswald and Freeman, 1981). A number of electron microscopic (EM) studies have shown specific $\alpha$-BTX receptors on retina neurons (Vogel and Nirenberg, 1976; Pourcho, 1979; Schwartz and Bok, 1979; Daniels and Vogel, 1980; Zucker and Yazulla, 1982), as have light microscopic autoradiographic studies (Yazulla and Schmidt, 1976). Although the assumption that the $\alpha$-BTX receptor is relevant to neuronal function still needs further corroboration (Morley and Kemp, 1981; Oswald and Freeman, 1981), the cellular specificity seen in our current data is suggestive of a physiological role. We present three findings: (1) only bipolar neurons have $\alpha$-BTX receptors; (2) receptors show a graded cell surface distribution, with most receptors found on dendrites; and (3) the number of receptors per cell within the bipolar class is variable, with displaced bipolar cells lacking receptors altogether.

\section{Materials and Methods}

Isolation of labeled cells and autoradiography. All chemicals except $\alpha$-BTX were obtained from Sigma Chemical Co., St. Louis, MO. $\left[{ }^{125} \mathrm{I}\right]-\alpha$-BTX was obtained from New England Nuclear, Boston, MA.

To prepare radiolabeled, dissociated cells from turtle retina, we modified the dissociation method of Sarthy and Lam (1978). Adult Pseudemys were decapitated and retinas were dissected into normal turtle medium (in grams per liter): $\mathrm{CaCl}_{2}, 0.2$; glucose, $2.0 ; \mathrm{KCl}, 0.25$; $\mathrm{MgCl}_{2}, 0.1 ; \mathrm{NaCl}, 7.3 ; \mathrm{NaH}_{2} \mathrm{CO}_{3}, 0.5 ; \mathrm{NaH}_{2} \mathrm{PO}_{4}, 0.07$. The retinas were incubated $3 \mathrm{hr}$ at $24^{\circ} \mathrm{C}$ in $\mathrm{Ca}^{2+}, \mathrm{Mg}^{2+}$-free buffered saline medium (CMF medium) with added EGTA (ethyleneglycol-bis-( $\beta$-aminoethylether)- $N, N^{\prime}$-tetra-acetate) at $5 \mathrm{~mm}$ and papain (Sigma P-3125) at 1.0 
$\mathrm{mg} / \mathrm{ml}$, adjusted to $\mathrm{pH} 7.2$ with $\mathrm{NaOH}$. To wash out papain, we used CMF medium without EGTA and with bovine serum albumin (BSA; fraction $V, 0.1 \mathrm{mg} / \mathrm{ml}$ ); wash medium was changed six times in $30 \mathrm{~min}$

To minimize the possibility of $\alpha$-BTX entering cells by diffusion, we used a modification of the toxin binding procedure of Yazulla and Schmidt (1976). Retinas were incubated in $\alpha$-BTX directly after wash ing out papain but before dissociating retinal neurons. Intact neural retinas were placed in CMF medium without EGTA containing a solution of $5 \mathrm{nM} \alpha-\mathrm{BTX}(97 \mathrm{Ci} / \mathrm{mmol})$ and with BSA for $1 \mathrm{hr}$ at $24^{\circ} \mathrm{C}$. After labeling, retinas were rinsed six times in $\mathrm{CMF}$ medium to remove unbound $\alpha$-BTX. To show only nonspecific binding, pieces of intact retina were processed to suppress specific binding by incubating in $d$ tubocurarine (Zucker and Yazulla, 1982) at a saturating $0.1 \mathrm{~mm}$ concentration (Vogel and Nirenberg, 1976) in all steps after papain.

To dissociate cells for autoradiography, treated tissue was minced into pieces of about a $10-\mathrm{mm}^{2}$ area, and these were triturated through a pipette in CMF medium. The cell suspension was quickly chilled to $4^{\circ} \mathrm{C}$, and glutaraldehyde was added to a final concentration of $1 \%$. Aliquots of cell suspension were placed on smooth porous filters $(\mathrm{Nu}-$ cleopore, Pleasanton, CA; polycarbonate capillary pore, $5 \mu \mathrm{m}$ ) that were floating on a solution of ice-cold glutaraldehyde $(1 \%)$ in sodium phosphate buffer (100 mM, pH 7.4) for $30 \mathrm{~min}$. Cells were rinsed by floating the filter on cold phosphate buffer $(100 \mathrm{mM})$ with many changes over $30 \mathrm{~min}$. To transfer cells to glass slides that had been precoated with a solution of poly-L-lysine $(0.1 \mathrm{mg} / \mathrm{ml})$, a filter was inverted on the slide and medium was absorbed through the filter with a wipe until the cells made contact with the slide; then the slide bearing the transferred cells was slowly inserted into distilled water to float the filter off of it. Slides were dried, dipped in Kodak NTB2 nuclear emulsion (diluted $1: 1$ with $\mathrm{dH}_{2} \mathrm{O} ; 42^{\circ} \mathrm{C}$ ), then air-dried again and stored for 90 days at $6^{\circ} \mathrm{C}$ with Dri-Rite; they were developed according to the manufacturer's instructions.

Filtration assays of specific binding. Retinas were treated with papain and were rinsed as above. Receptors were usually labeled prior to homogenization; however, for saturation experiments, receptors were labeled after membranes were prepared in CMF medium. In either case, duplicate samples of homogenate were prepared with or without $d$-tubocurarine. Membranes were filtered on Whatman $\mathrm{GF} / \mathrm{C}$ filters (presoaked in BSA, $0.1 \mathrm{mg} / \mathrm{ml}$ ) and were washed with $20 \mathrm{ml}$ of medium. The filters were air-dried, and radioactivity was measured by liquid scintillation counting. Protein was measured by a modified Lowry method (Markwell et al., 1978). Dissociation of specific $\alpha$-BTX binding was measured with or without saturating $d$-tubocurarine, preincubating for 60 min at $24^{\circ} \mathrm{C}$, and assaying as described.

Receptor numbers per cell were calculated from counts of autoradiographic grains using the following formula (modified from Fertuck and Salpeter, 1976):

$$
N=\left(d n / S_{0}\right)\left(2.17 \times 10^{3}\right) /\left(1-e^{-0.01155 t}\right)
$$

where $N$ is the number of receptors per cell, $d$ is the number of decays to give one developed grain, $n$ is the number of developed grains counted on that cell, $S_{0}$ is the initial specific activity of the radioligand, and $l$ is the exposure time in days. The reciprocal efficiency, $d$, was assumed to be approximately 2 (Fertuck and Salpeter, 1976).

\section{Results}

Classes of cells obtained. Cell classes that others have described using silver and dye stains were abundant in our preparations. In identifying cells, we relied on previous studies for standard morphological criteria. Rod and cone photoreceptors were abundant and had synaptic or dendritic processes, but most lacked an outer segment (Fig. 1, $C$ and $F$, rod and cone, respectively); Müller cells (neuroglia, Fig. 1A; Sarthy and Lam, 1979a) had long, unbranched processes that were fuzzy and ended in a varicosity. The multipolar neurons seen included horizontal cell bodies (Fig. 1, $B$ and $D$ ) and their axon terminals, which were detached here (Fig. $1 E$; Leeper, 1978). Amacrine cells (Fig. 1, $G$ and $I$ ) and ganglion cells (Fig. $1 H$; Kolb and Jones, 1982) were seen least frequently. Isolated bipolar cells were plentiful and showed specialized morphological details allowing identification of specific bipolar cell types (shown and discussed below). Levels of magnification are identical in all figures.
Unchanged $\alpha-B T X$ binding after papain treatment. We assessed the persistence of specific $\alpha$-BTX binding in cells dissociated with papain to determine their potential usefulness for autoradiography. Retinas were treated with either papain-CMF or CMF medium, and after either treatment, $\alpha$-B'TX binding was virtually the same. Binding was always blocked by $d$ tubocurarine, a well known nicotinic antagonist (e.g., Masland, 1980; Glickman et al. 1982), and was saturated by $5 \times 10^{-9} \mathrm{M}$, as expected for binding to the specific $\alpha$-BTX receptor (Yazulla and Schmidt, 1976). A saturating concentration of toxin was used in all subsequent experiments. Although receptor concentrations varied in individual turtles and in different lots, both control and papain-treated membranes had approximately equal concentrations of receptors $(120 \pm 50 \mathrm{fmol} / \mathrm{mg}$ of protein). As might be expected from the high affinity of the binding equilibrium, dissociation of the ligand from the papain-treated receptor was slow. Over a time of $90 \mathrm{~min}$, only a slight decline $(15 \%)$ was found in specifically bound $\alpha$-BTX. Both saturation and dissociation experiments were consistent with the goal of receptor localization using autoradiography.

Bipolar cells seen with the procedure. Autoradiography was performed on mass-isolated cells in order to study the cellular and subcellular localization of receptors. Of thousands of cells autoradiographed, most cells had few grains over them (Fig. 1) and were indistinguishable from controls with $d$-tubocurarine (not shown). The bipolar cell population was the exception (Figs. 2 and 3), being the only class ever seen with grain densities above background.

Isolated bipolar cells had the usual segmental parts, as observed in the retina (Ramón y Cajal, 1972; Richter and Simon, 1975; Yazulla, 1976; Granda and Dvorak, 1977; Weiler, 1981; Dacheux, 1982; Kolb, 1982) or in isolation (Sarthy et al., 1981). The nucleus appeared phase-dark within the cell body (Fig. 4) and, in most cells, its central position was far from the branches of its main processes. A Landolt club (Landolt, 1871) branched from either the main or a collateral dendrite (except in displaced type cells as described below), and its shape was tapered or bulbous. Axons were mostly smooth and unbranched, but in some a collateral branched from the shaft (Fig. $4 B$ ). The axon terminals ended as either a single bulb or as one or more fine processes. The lengths of the hipolar cells varied considerably, with a maximum of about $150 \mu \mathrm{m}$.

The figures show both brightfield and phase optics pictures to more easily establish the relationship between grain density and cell morphology. Bipolar cells were seen mostly as individuals, but they occasionally were found in clusters (Figs. 2 and $3)$. Coherent alignment of cells, sometimes with photoreceptors (Fig. $2 A$ ) and horizontal cells, suggested that they still had natural anatomical relationships. Within clusters of cells, grain deposits often occurred over one bipolar cell but not another (Figs. 2 and $3, A$ and $B$ ). Labeling was thus highly selective. Some clusters included mostly labeled cells (Fig. 2, $B$ and $C$ ), but other clusters included only unlabeled cells (Fig. $2 A$ ). The data thus show that bipolar cells themselves selectively expressed cell surface macromolecules.

As the data showed that only some bipolar cells expressed receptor molecules, we next asked if receptor-positive bipolar cells had equal grain densities. As can be seen (Figs. 3 to 7), some cells had many receptors, whereas others had fewer or none. A survey of 258 bipolar cells showed variable labeling that was heavy in $12 \%$, moderate in $13 \%$, light in $7 \%$, and absent in $68 \%$ (including virtually all displaced bipolar cells). Autoradiographic grains were counted and the number of receptors per cell was calculated. The highly labeled cells shown (Fig. 3) had about 30,000 receptor sites each, moderately labeled cells (Fig. 5) had about 10,000 sites, and lightly labeled cells (Fig. 6) had about 5,000 sites. Intermediate levels also were 

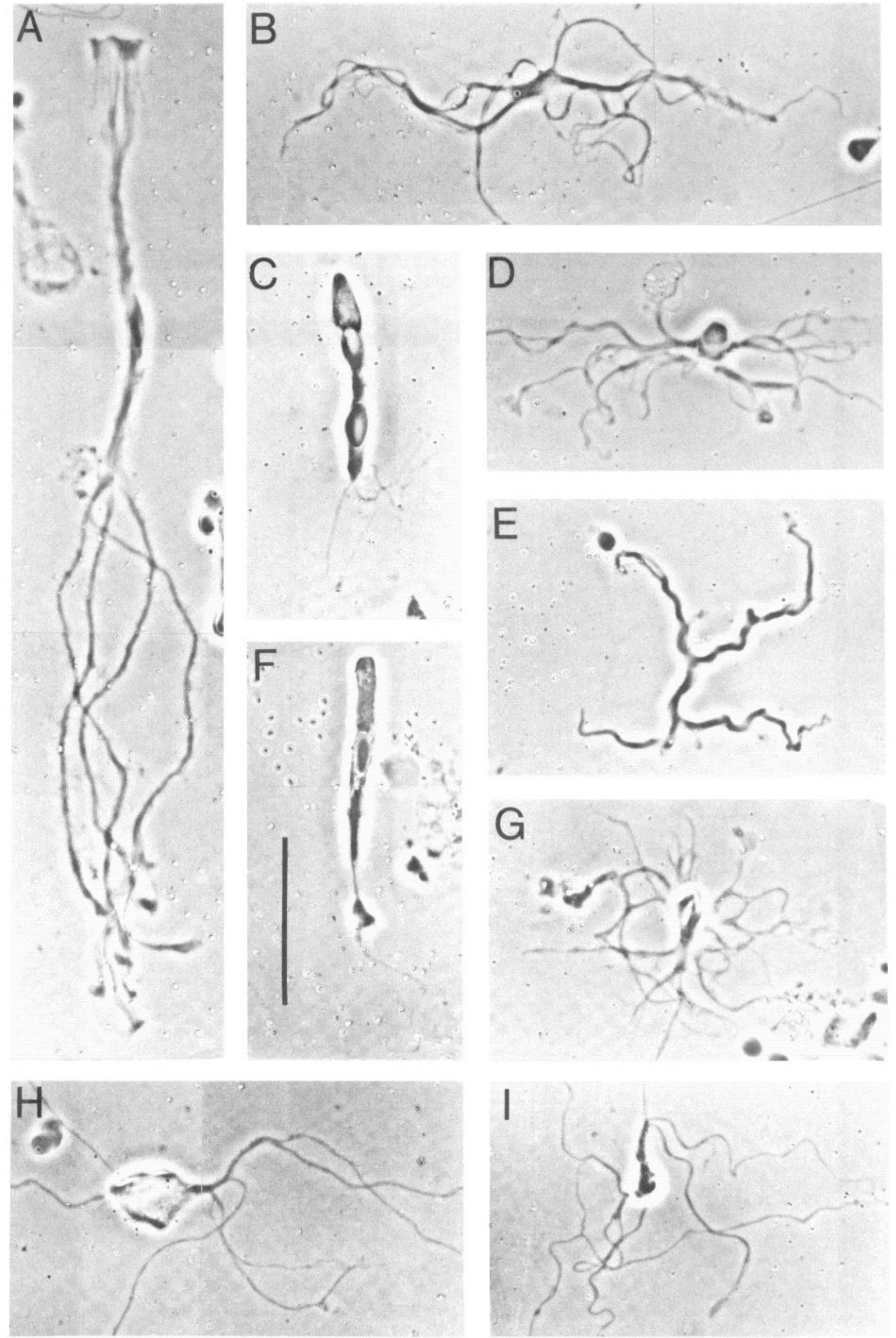

Figure 1. Multipolar and photoreceptor cells seen in dissociates of turtle retina after autoradiography for [ $\left.{ }^{125} \mathrm{I}\right] \alpha-\mathrm{BTX}$ receptors (phase contrast). All of these cells lacked concentrations of grains and hence were receptor free. Shown are: $A$, Müller (neuroglia) cell; $B$, H2 horizontal cell; $C$, rod photoreceptor; $D, \mathrm{H} 1$ horizontal cell; $E$, H1 horizontal cell axon terminal; $F$, cone photoreceptor; $G$, amacrine cell; $H$, ganglion cell; $I$, amacrine cell. Cell segments which would be directed outward in the retina are shown directed upward. Scale bar $(F)=30 \mu \mathrm{m}$. 

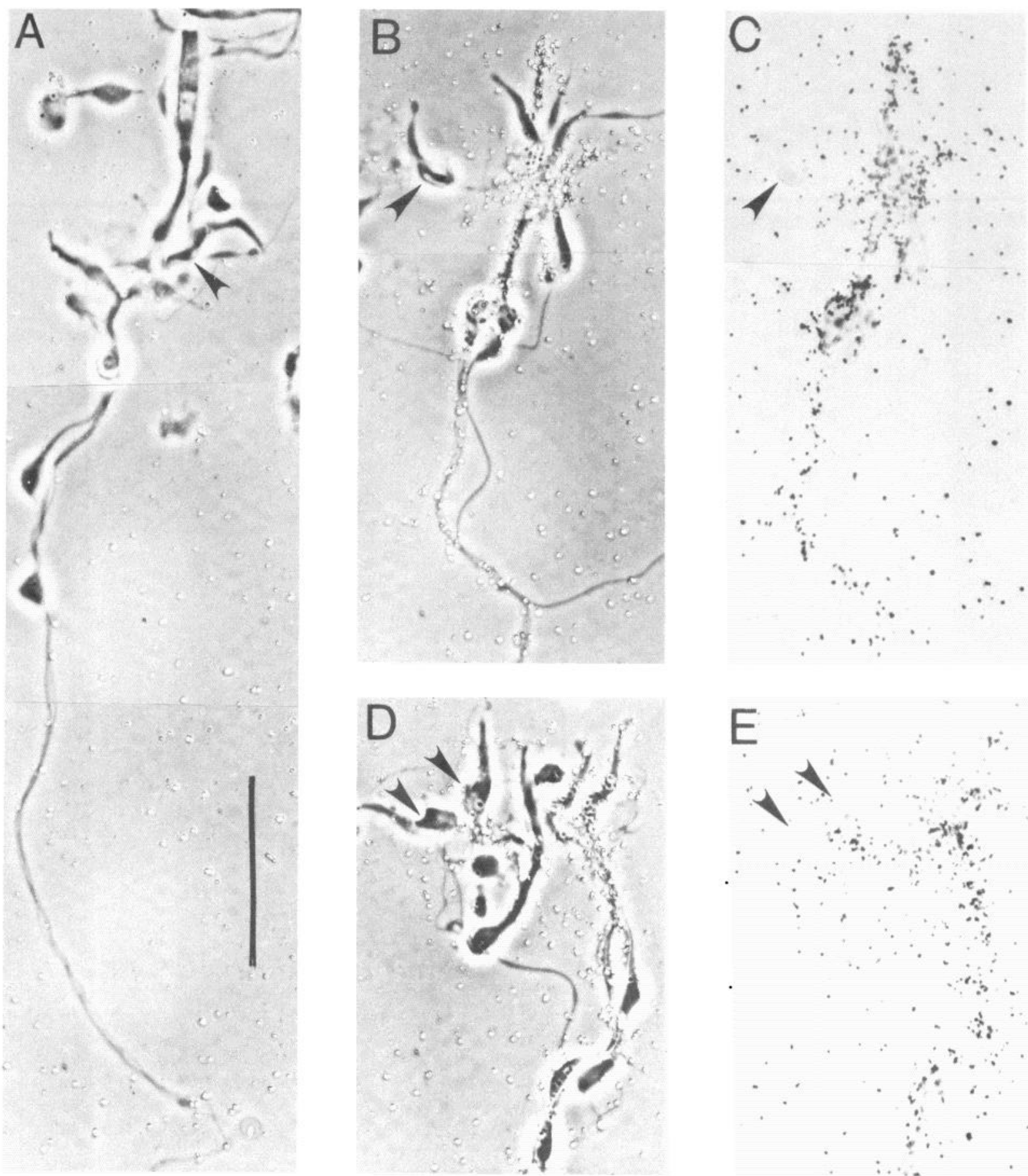

Figure 2. Cell-selective labeling of bipolar cells retaining their natural anatomical relationships in clusters (grains are bright in phase contrast $(A, B$, and $D)$ and are dark in paired brightfield $(C$ and $E)$. Grains were always sparse or absent over displaced-type bipolar cell bodies (arrowheads). A photoreceptor is shown in $A$ at the top. Some clusters included no labeled cells $(A)$ ). Other clusters included both labeled and unlabeled cells (pairs $B-C$ and $D-E$ ). This showed both cell-selective labeling and showed that particular kinds of bipolar cells have different numbers of receptors per cell. Scale bar $=30 \mu \mathrm{m}$.

evident. Thus, $\alpha$-BTX receptors did not appear to be expressed "all or none."

Receptors were concentrated at the dendritic poles of the bipolar cells, but other segments were also labeled. The axon had a portion of the grains that varied from $5 \%$ to $40 \%$. Grain distribution within a segment often appeared heterogeneous, but no clear-cut evidence for micropatches of receptors was obtained (Figs. 3 and 5).

Differential labeling within the class of bipolar cells led us to ask whether bipolar cells with a specific type of morphology had identical receptor expression. However, only a few kinds of isolated bipolar cells could be identified by reference to the Golgi-stained bipolar types designated in Kolb's (1982) study, mainly because of the difficulty in preserving axon terminals and in determining the level of stratification of terminals in the inner plexiform layer (IPL). Of these kinds, cells similar to Kolb's B2 bipolar type were particularly abundant (18\% of bipolar cells). In B2 cells, the dendrites branch close to or directly from the cell body (Kolb, 1982). The cell body is either above (displaced form) or below (regular form) the dendritic 

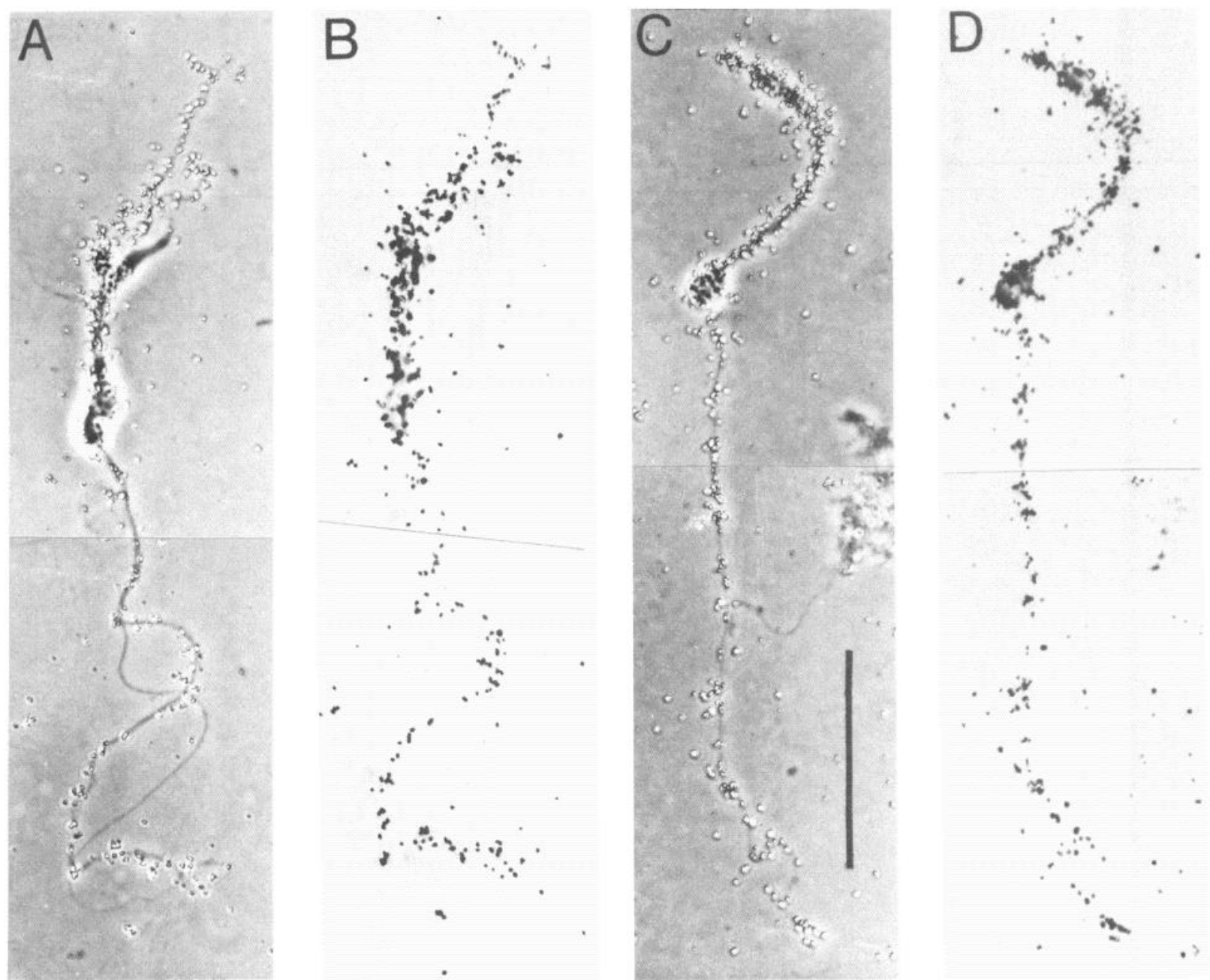

Figure 3. Highly labeled bipolar cells showing receptors over all segments, including the axon shaft and its terminals. Dendrites were covered by grains, and those in $C$ and $D$ adhered to the Landolt club and its shaft. Only one of the two clustered cells in the pair $A-B$ had grains, showing selective binding of $\alpha$-BTX. Grains on axon shafts were not distributed homogeneously. Calculations from grain counts indicated about 30,000 receptors on each cell. Scale $b a r=30 \mu \mathrm{m}$ (phase contrast in $A$ and $C$; paired brightfield in $B$ and $D$ ).

branches. Although there may be other bipolar types that can assume the displaced form, most displaced cells are of the B2 type (H. Kolb, personal communication).

In isolated displaced bipolar cells (Figs. $2, B$ and $E$, and 7 ), the Landolt club sometimes fused with the cell body, which contained a phase-dark nucleus. The axon at the lower pole of the cell body was smooth, slightly tapered, unbranched except for dendrites, and about $100 \mu \mathrm{m}$ long. Dendrites emerged either from the lower pole of the cell body or from the nearer part of the main process (Fig. $7 D$ ). More than 50 displaced bipolar cells were seen in isolation, yet none was labeled above background. Likewise, displaced cells which occurred in natural cell clusters (Fig. 2, $B$ and $E$, arrowheads) had no developed grains over them.

At least three other types of bipolar cells can lack receptors. Some unlabeled cells had similar overall lengths, but the portion of their length that was due to the length of their axon varied greatly (Fig. 4). One of these cells that had an axon collateral branch (Fig. $4 B$ ) may be a bistratified type. Axons of the others did not appear to have branches and were therefore difficult to assign to cells of Kolb's (1982) classification. They could have been either monostratified or bistratified types with inadequately preserved terminals.

\section{Discussion}

The data demonstrate the occurrence of molecular heterogeneity within a population of differentiated CNS neurons.
Using light microscopic autoradiography to localize $d$-tubocurarine-sensitive $\alpha$-BTX receptors on cells isolated from the turtle retina, we found that: (1) of the six major cell classes in the turtle retina, only bipolar cells had $\alpha$-BTX receptors, (2) bipolar cells had a broad range of receptor sites per cell, as opposed to "all or none" occurrence, and (3) receptors showed no obvious clustering or strict localization at the subcellular level, but their distribution suggested a positional gradient with the majority of receptors found on dendrites.

Nature and function of sites. The nature and function of $\alpha$ BTX receptors on neurons is still somewhat controversial. However, $\alpha$-BTX binds to a specific molecular substrate that is enriched in brain regions where other cholinergic markers occur (reviewed by Fibiger, 1982) and in isolated synaptic structures (reviewed in Morley and Kemp, 1981; Oswald and Freeman, 1981). Zucker and Yazulla (1982) and Glickman et al. (1982) have suggested that the receptor plays some specific role in nicotinic synapses in the goldfish retina. Oswald and Freeman (1981) have shown that the $\alpha$-BTX receptor may be involved in retina-tectal transmission in the turtle and may be necessary for maintenance of appropriate intercellular connections in the optic tectum of the goldfish and the toad. In the retina, previous studies of $\alpha$-BTX receptor binding have established its nicotinic specificity (Vogel and Nirenberg, 1976; Yazulla and Schmidt, 1976; Schwartz and Bok, 1979; Zucker 

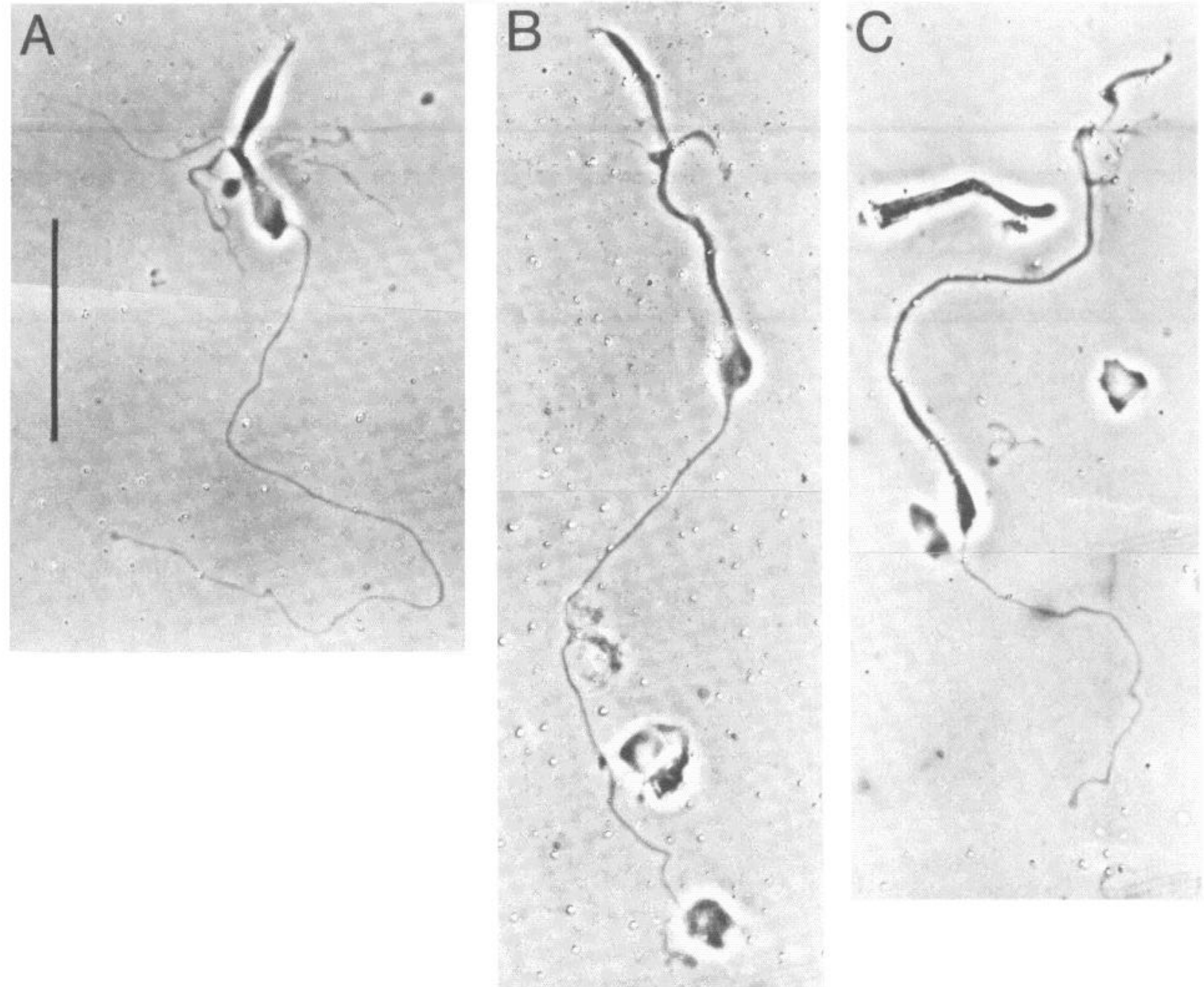

Figure 4. Unlabeled bipolar cells of three different types. Note that the relative proportions of the axons and the dendrites differ. The cell in $A$ has a very short primary dendrite that is one-twentieth of the length of its axon, the proportion in $B$ is one-fourth, and in $C$ the dendrite is longer than the axon. The cell in $B$ has a varicosity from which emerges an axon collateral branch, showing that this cell was a bistratified type. Scale bar $=30 \mu \mathrm{m}$ (phase contrast).

and Yazulla, 1982), and nicotinic cholinergic drugs affect physiological activity of ganglion cells in the IPL of the carp (Negishi et al., 1978; Glickman et al. 1982). Recently, the $\alpha$ BTX receptor from avian CNS has been purified and shown to have considerable homology with the nicotinic receptor of skeletal muscle (Norman et al., 1982).

Our finding of $\alpha$-BTX binding to isolated bipolar cells and not to horizontal cells (in which photoresponses are not affected by nicotinic drugs but are by muscarinic drugs; Gerschenfeld and Piccolino, 1977) is suggestive of a physiologically specific role for the receptors. The ACh-synthetic activity of neurons that have synaptic contact with bipolar cells is further evidence for a physiological role for $\alpha$-BTX receptors. Baughman and Bader (unpublished, cited in a review by Masland, 1980) have shown that specific sets of cholinergic amacrine cells can account for ACh synthesis in the IPL (Ross and McDougal, 1976). If cholinergic amacrines synapse on bipolar cells, we would expect to see $\mathrm{ACh}$ receptors on axons of these cells in autoradiographs, as we do in some, but not all, bipolar cells. ACh synthesis also occurs in the outer plexiform layer (OPL) (Ross and McDougal, 1976), and Sarthy and Lam (1979b) have found choline acetyltransferase (CAT) activity in the photoreceptors of the turtle. $\alpha$-BTX receptors are maximal in the OPL of the turtle (Yazulla and Schmidt, 1976) and, as shown here, these are preferentially located on dendrites of bipolar cells. Thus, the correlation between CAT activity and receptor localization in the turtle is consistent with nicotinic cholinergic communication from some photoreceptors and from a variety of amacrine cells to some bipolar cells.

Receptor distribution on bipolar cells. Bipolar cells are distinguished from other turtle retina cells by their abundance of $\alpha$ BTX receptors. Within the bipolar cell population itself, cells are differentiated further with respect to receptor expression. We have found that the number of receptors per cell was continuously variable, rather than "all or none," and that specific types of bipolar cells could be labeled or unlabeled. The maximum number of $\alpha$-BTX receptors per cell was 30,000 receptors/cell, assuming an estimated emulsion efficiency of 0.5 developed grains/decay (Fertuck and Salpeter, 1976). Apparently, the quantitative regulation of the $\alpha$-BTX receptor phenotyope is finely tuned. Earlier studies of the number of $\alpha$ BTX receptors measured in cultured avian retina cells have indicated that membrane potential or chemical modulators (Betz, 1983) but not agonist activation (Siman and Klein, 1983) might play a role in their regulation.

We have shown that there are at least three kinds of bipolar cells that lack $\alpha$-BTX receptors: the B2 displaced and probably the $\mathrm{B} 2$ regular type, and one bistratified and one monostratified 

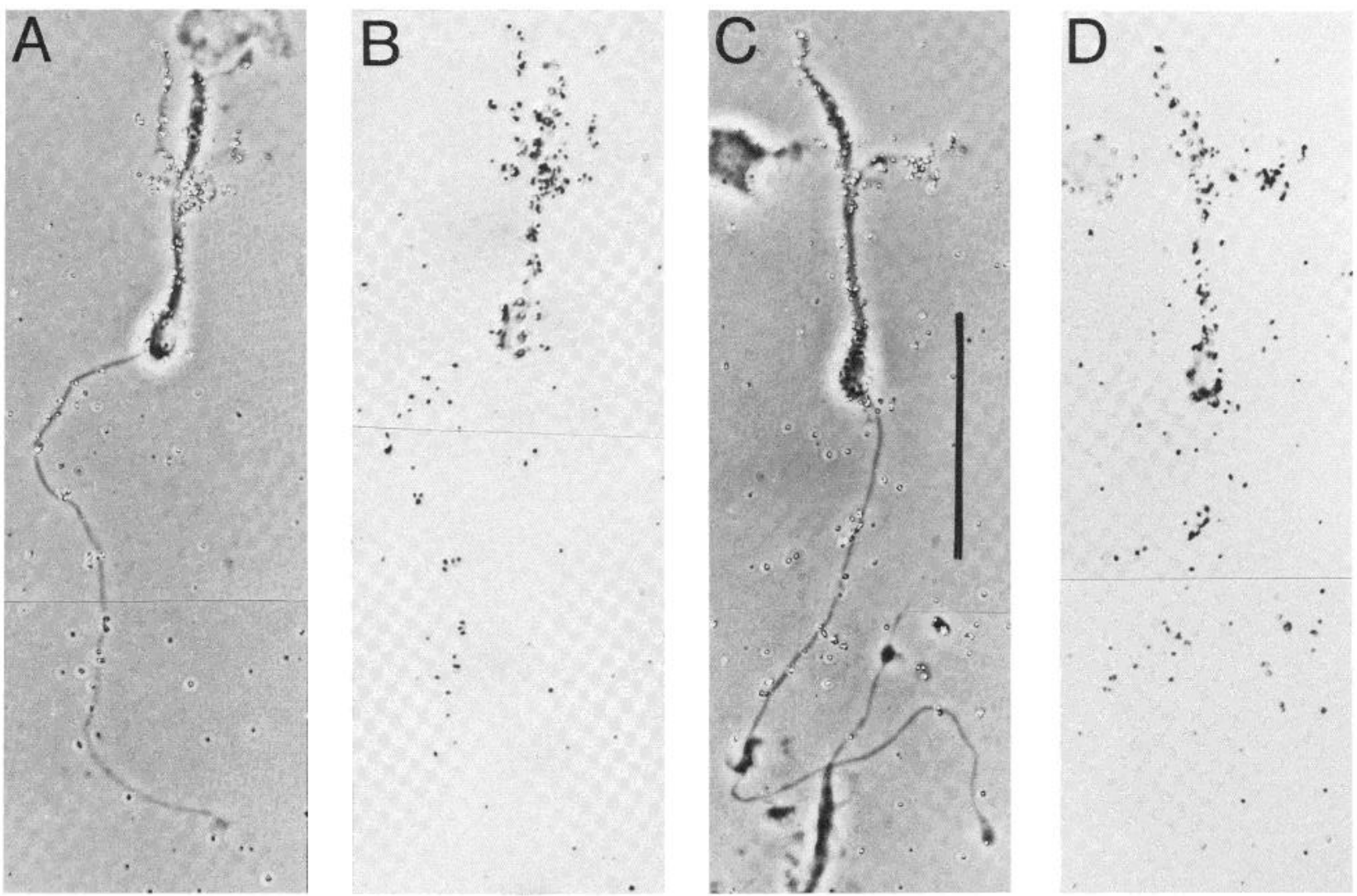

Figure 5. Bipolar cells with moderate receptor levels. Axons shown ended in bulbs, and dendrites adhered together. Calculations from grain counts indicated $12,700(A$ and $B)$ or $9,700(C$ and $D)$ receptors/cell, of which about $15 \%$ were on axons. Scale bar $=30 \mu \mathrm{m}$ (phase contrast in $A$ and $C$; paired with brightfield in $B$ and $D$ ).

Figure 6. A bipolar cell with a low receptor level, calculated to be 4500 receptors. Scale bar $=30$ $\mu \mathrm{m}$ (phase contrast paired with brightfield).
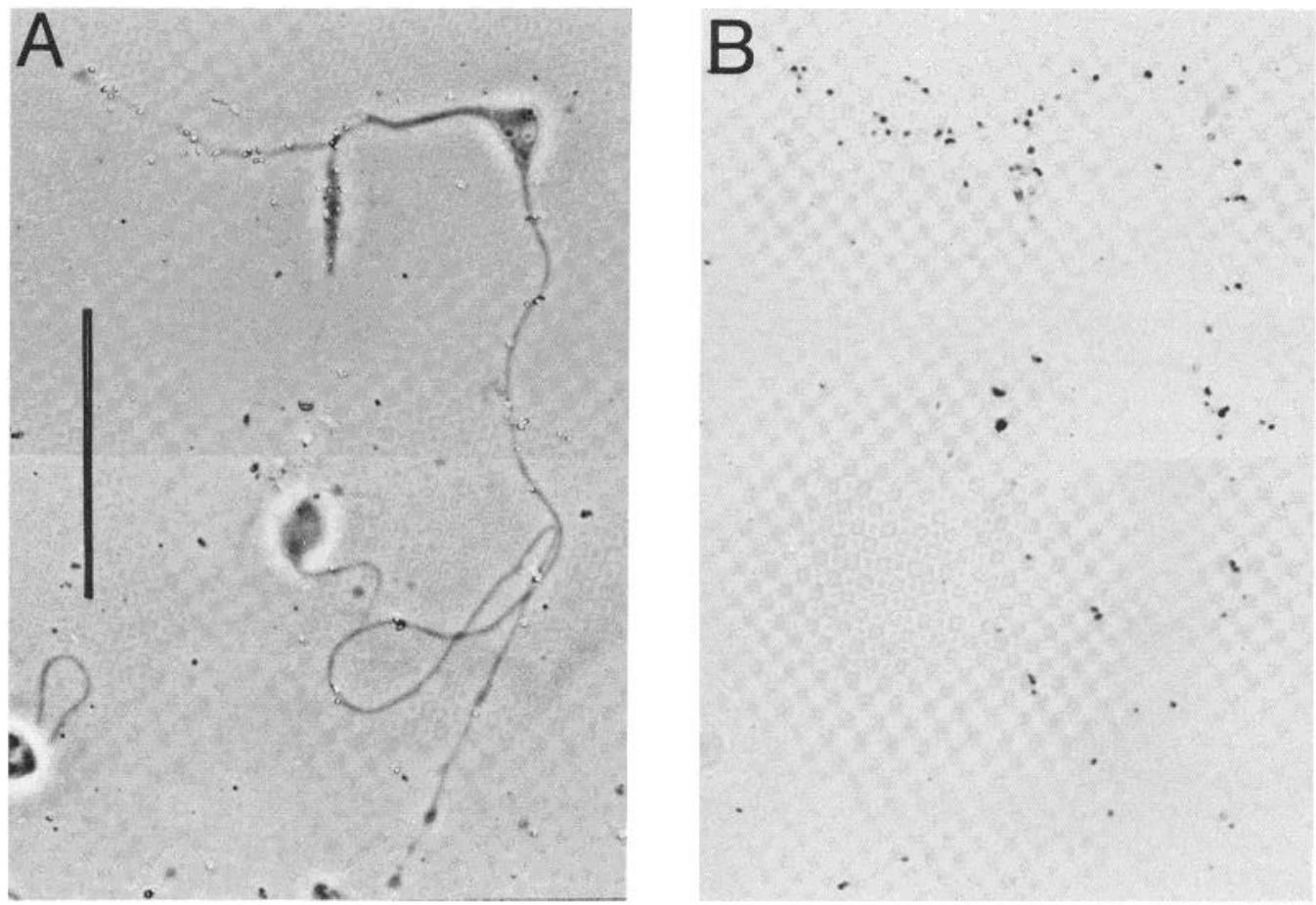

type. The isolated displaced bipolar cells were all receptor free. This may be their invariant condition and, thus, is analogous to the invariant lack of $\alpha$-BTX receptors on other major classes of retinal neurons. The presence of cell clusters, in which labeled and unlabeled cells intermingled, suggested the idea that such cells need not be in separate domains in the retina, although some unlabeled clusters suggested such domains might also exist.

Our data and those of others are consistent with the occurrence of both synaptic and nonsynaptic $\alpha$-BTX receptors in the turtle retina. In addition to dendritic receptors, we found substantial grain deposits on cell bodies and on adjacent parts 


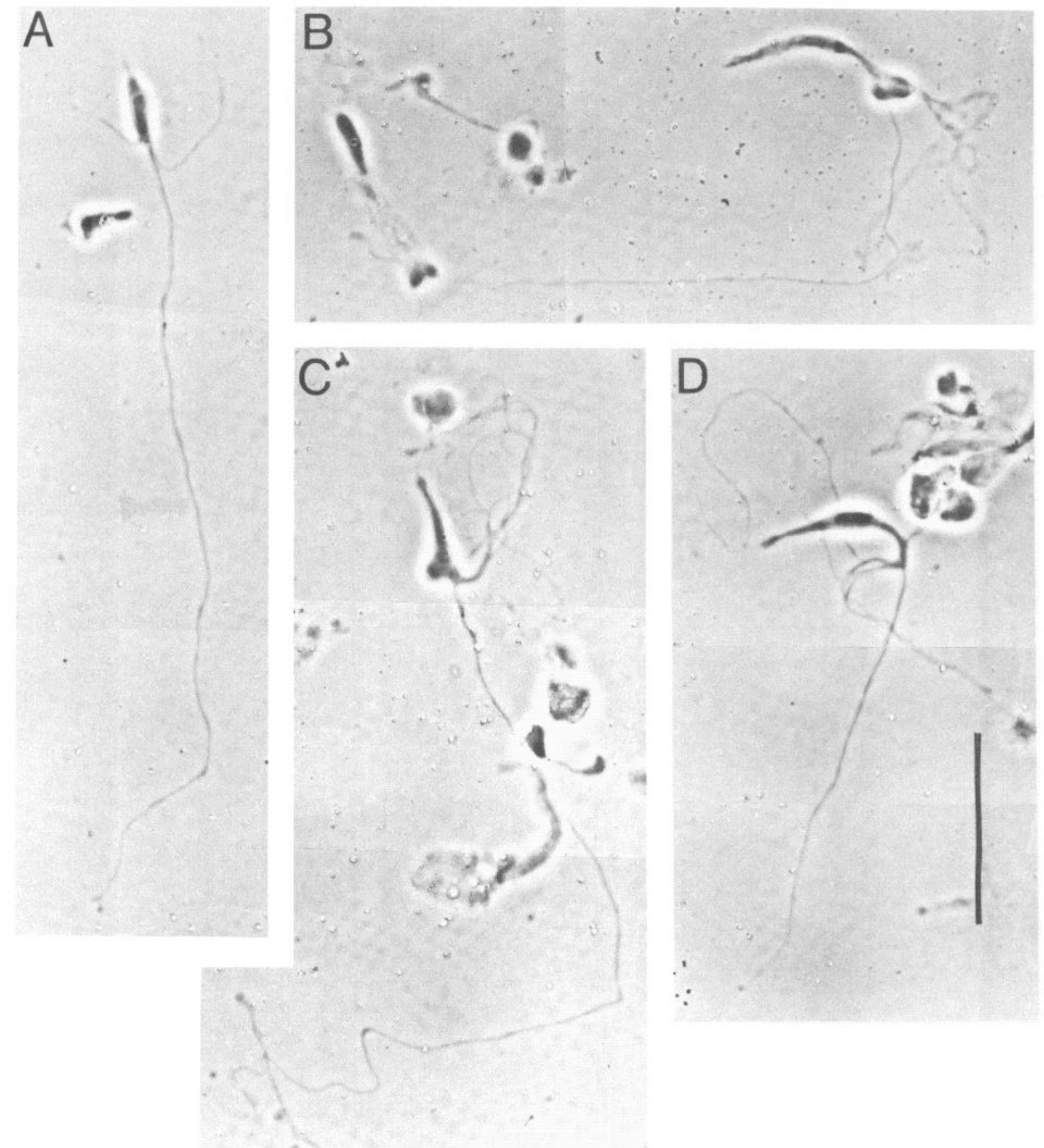

Figure 7. Displaced-type bipolar cells showed little or no receptor binding. The cell body is next to and above the dendritic branches. The origin of the dendrites may be from the equator $(B)$ or the lower pole of the cell body $(A$ and $C$ ), or slightly below the cell body on the long ( 100 $\mu \mathrm{m})$ principal axonal process $(D)$. The Landolt club, when not fused with the cell body $(A)$, emerged directly from it $(B$ to $D)$. Axons end in small, sometimes bulbous $(A$ and $B)$ varicosities. This unique morphology allowed for identification of this cell type as a variant of the B2 type (153) of Kolb (1982). Compare some of these cells in clusters (Fig. 2, arrowheads). Scale bar $=30 \mu \mathrm{m}$ (phase-contrast).

of primary processes (Figs. 2,3, and 5). Bodies of bipolar cells in the inner nuclear layer are not usually in contact with terminals of neuronal processes, so that they have not been supposed to possess synaptic contacts. Similarly, others have shown $\alpha$-BTX receptors in the inner nuclear layer of turtle (Yazulla and Schmidt, 1976) and fish (Schwartz and Bok, 1979). Zucker and Yazulla's (1982) EM study of $\alpha$-BTX receptor localization in goldfish retina shows that some synaptic receptors but mostly nonsynaptic receptors occur in the IPL. Schwartz and Bok (1979) have similar findings in the OPL.
Some EM studies show $\alpha$-BTX receptors exclusively to be at synapses in the IPL of the chicken (Daniels and Vogel, 1980) and the mouse (Pourcho, 1979). Likewise, $\alpha$-BTX receptors are highly localized to dendritic surfaces of optic tectum neurons (reviewed by Oswald and Freeman, 1981). The cytochemically designated sites are usually thought to represent micropatches of receptors (Daniels and Vogel, 1980). We could not distinguish between random localization and the presence of such micropatches in turtle bipolars, but our impression is that receptors are not homogeneously distributed on axons or dendrites of isolated cells. 
Receptor positioning on retinal cells may depend on specific directive mechanisms, perhaps involving the cytoskeleton (Gulley and Reese, 1983). In innervated muscle cells, subjunctional $\alpha$-BTX receptors are relatively immobile (reviewed by ContiTronconi and Raftery, 1982), inserted at the subjunctional membrane (Salpeter and Harris, 1983), and associated with the cytoskeleton (Bloch and Hall, 1983; Peng, 1983). Whereas muscle cells have been widely studied to dissect the molecular mechanisms of receptor localization (Pumplin and Fambrough, 1982), an adequate cellular preparation that would be amenable to similar studies of central neurons has been lacking until now.

Our demonstration that a certain population of neurons in the turtle retina can be isolated, identified, and stained for specific receptors indicates the feasibility of these techniques. Presumably, other specific receptors, such as muscarinic ACh (James and Klein, 1982), lectins (Sarthy et al., 1981), $\mathrm{Na}^{+}$ channels (Sarthy et al., 1983), and defined antigens (McKay et al., 1981; Lindstrom et al., 1983) label readily and may be studied. Mammalian cells (Sarthy and Lam, 1979a) and avian cells (James and Klein, 1984) may also be isolated and made amenable for study. Thus, for a number of molecules and nerve cell types, important questions about receptor position, function, development, and metabolism can now be readily investigated.

\section{References}

Barondes, S. H. (1976) Neuronal Recognition, Plenum Press, New York. Bartfeld, D., and S. Fuchs (1979) Active acetylcholine receptor fragment obtained by tryptic digestion of acetylcholine receptor from Torpedo californica. Biochem. Biophys. Res. Commun. 89: 512-519.

Betz, H. (1983) Regulation of $\alpha$-bungarotoxin receptor accumulation in chick retina cultures: Effects of membrane depolarization, cyclic nucleotide derivatives, and $\mathrm{CaCl}_{2}$. J. Neurosci. 3: 1333-1341.

Bloch, J. R., and Z. W. Hall (1983) Cytoskeletal components of the neuromuscular junction: Vinculin, $\alpha$-actinin, and filamin. J. Cell Biol. 97: 217-223.

Conti-Tronconi, B. M., and M. A. Raftery (1982) The nicotinic cholinergic receptor: Correlation of molecular structure with functional properties. Annu. Rev. Biochem. 51: 491-530.

Dacheux, R. F. (1982) Connections of the small bipolar cells with the photoreceptors in the turtle. An electron microscope study of goldtoned retinas. J. Comp. Neurol. 205: 5562

Daniels, M. P., and Z. Vogel (1980) Localization of $\alpha$-bungarotoxin binding sites in synapses of developing chick retina. Brain Res. 201. $45-56$.

Fertuck, H. C., and M. M. Salpeter (1976) Quantitation of junctional and extrajunctional acetylcholine receptors by electron microscope autoradiography after $\left[{ }^{125} \mathrm{I}\right]-\alpha$-bungarotoxin binding at mouse neuromuscular junction. J. Cell Biol. 69: 144-158.

Fibiger, H. C. (1982) The organization and projection of some cholinergic neurons of the mammalian forebrain. Brain Res. Rev. 4: 327 388 .

Gerschenfeld, H. M., and M. Piccolino (1977) Muscarinic antagonists block cone to horizontal cell transmission in turtle retina. Nature 268: $257-259$.

Glickman, R. D., A. R. Adolph, and J. E. Dowling (1982) Inner plexiform circuits in the carp retina: Effects of cholinergic agonists, GABA, and substance $\mathrm{P}$ on the ganglion cells. Brain Res. 234: 8199.

Granda, A. M., and C. A. Dvorak (1977) Vision in turtles. In Handbook of Sensory Physiology, F. Crescitelli, ed., Vol. VII, pp. 451-495, Springer-Verlag, New York.

Gulley, R. L., and T. S. Reese (1983) Cytoskeletal organization at the postsynaptic complex. J. Cell Biol. 91: 298-302.

James, W. L. [M.] and W. L. Klein (1982) Autoradiography of dendritic acetylcholine receptors: A method for study of isolated neurons from the adult central nervous system of the turtle. Neurosci. Lett. 32: 510 .

James, W. M., and W. L. Klein (1984) Localization of nicotinic and muscarinic acetylcholine receptors in neurons isolated from chick embryo retina. Soc. Neurosci. Abstr. 10: 35 .

Klymkowsky, M. W., J. E. Heuser, and R. M. Stroud (1980) Protease effects on the structure of acetylcholine receptor membranes from Torpedo californica. J. Cell Biol. 85: 823-838.

Kolb, H. (1982) The morphology of the bipolar cells, amacrine cells and ganglion cells in the retina of the turtle Pseudemys scripta elegans. Philos. Trans. R. Soc. Lond. (Biol.) 298: 355-393.

Kolb, H., and J. Jones (1982) Light and electron-microscopy of the photoreceptors in the retina of the red-eared slider, Pseudemysscripta elegans. J. Comp. Neurol. 209: 331-338.

Landolt, E. (1871) Beitrag zur Anatomie der Retina vom Frosch, Salamander und Triton. Arch. Mikrosk. Anat. Entwicklungsgesch. Mech. 7: 81-100.

Leeper, H. F. (1978) Horizontal cells of the turtle retina. J. Comp. Neurol. 182: 777-794.

Lindstrom, J., W. Gullick, B. Conti-Tronconi, and M. Ellisman (1980) Proteolytic nicking of the acetylcholine receptor. Biochemistry 19: 4791-4795.

Lindstrom, J., S. Tzartos, W. Gullick, S. Hochschwender, L. Swanson, P. Sargent, M. Jacob, and M. Montal (1983) Use of monoclonal antibodies to study acetylcholine receptors from electric organs, muscle, and brain, and the autoimmune response to receptor in myasthenia gravis. Cold Spring Harbor Symp. Quant. Biol. 48: 8999.

Markwell, M. A. K., S. M. Haas, L. L. Bieber, and N. Tolbert (1978) A modification of the Lowry procedure to simplify protein determination in membrane and lipoprotein samples. Anal. Biochem. 87: 206210.

Masland, R. H. (1980) Acetylcholine in the retina. Neurochemistry 1 : 501-518.

McKay, R., C. R. Raff, and L. F. Reichardt (1981) Monoclonal Antibodies to Neural Antigens, Cold Spring Harbor Laboratory, Cold Spring Harbor, NY.

Morley, B. J., and G. E. Kemp (1981) Characterization of a putative nicotinic acetylcholine receptor in mammalian brain. Brain Res. Rev. 3: 81-104.

Negishi, K., S. Sato, T. Teranishi, and M. Laufer (1978) An electrophysiological study on the cholinergic system in the carp retina. Brain Res. 148: 85-93.

Norman, R. I., F. Mehraban, E. A. Barnard, and J. O. Dolly (1982) Nicotinic acetylcholine receptor from chick optic lobe. Proc. Natl. Acad. Sci. U. S. A. 79: 1321-1325.

Oswald, R. E. and J. A. Freeman (1981) $\alpha$-Bungarotoxin binding and central nervous system nicotinic receptors. Neuroscience 6: 1-14.

Peng, H. B. (1983) Cytoskeletal organization of the presynaptic nerve terminal and the acetylcholine receptor cluster in cell cultures. $\mathrm{J}$. Cell Biol. 97: 489-498.

Pourcho, R. G. (1979) Localization of cholinergic synapses in mammalian retina with peroxidase-conjugated $\alpha$-bungarotoxin. Vision Res. 19: 287-292

Pumplin, D. W., and D. M. Fambrough (1982) Turnover of acetylcholine receptors in skeletal muscle. Annu. Rev. Physiol. 44: 319-335.

Ramón y Cajal, S. (1972) The Structure of the Retina, S. A. Thorpe and M. Glickstein, eds., Charles C Thomas, Springfield, IL.

Richter, A., and E. J. Simon (1975) Properties of centre-hyperpolarizing, red-sensitive bipolar cells in the turtle retina. J. Physiol. (Lond.) 248: $317-334$

Ross, C. D., and D. B. McDougal (1976) The distribution of choline acetyltransferase activity in vertebrate retina. J. Neurochem. 26 521-526.

Salpeter, M. M., and R. Harris (1983) Distribution and turnover rate of acetylcholine receptors throughout the junction folds at a neuromuscular junction. J. Cell Biol. 96: 1781-1785.

Sarthy, P. V., and D. M. K. Lam (1978) Biochemical studies of isolated glial (Muller) cells from turtle retina. J. Cell Biol. 78: 675-684.

Sarthy, P. V., and D. M. K. Lam (1979a) Isolated cells from a mammalian retina. Brain Res. 176: 208-212.

Sarthy, P. V., and D. M. K. Lam (1979b) Endogenous levels of neurotransmitter candidates in photoreceptor cells of the turile retina. $J$ Neurochem. 32: 455-461.

Sarthy, P. V., C. D. Bridges, F. L. Kretzer, and D. M. K. Lam (1981) Lectin receptors on cells isolated from the turtle retina. J. Comp Neurol. 202: 561-569.

Sarthy, P. V., B. M. Curtis, and W. A. Catterall (1983) Retrograde laheling, enrichment, and characterization of retinal ganglion cells from neonatal rat. J. Neurosci. 3: 2532-2544.

Schwartz, I. R., and D. Bok (1979) Electron microscopic localization of 
$\left[{ }^{125} \mathrm{I}\right]-\alpha$-bungarotoxin binding sites in the outer plexiform layer of the goldfish retina. J. Neurocytol. 8: 53-66.

Siman, R. G., and W. L. Klein (1983) Differential regulation of muscarinic and nicotinic receptors by cholinergic stimulation in cultured avian retina cells. Brain Res. 262: 99-108.

Stevens, C. F. (1979) The neuron. Sci. Am. 241: 54-65.

Vogel, Z., and M. Nirenberg (1976) Localization of acetylcholine receptors during synaptogenesis in retina. Proc. Natl. Acad. Sci. U. S. A. 73: $1806-1810$.

Weiler, R. (1981) The distribution of center-depolarizing and centerhyperpolarizing bipolar cell ramifications within the inner plexiform layer of turtle retina. J. Comp. Physiol. 144: 459-464.
Wenogle, L. P., R. Oswald, T. Saitoh, and J. -P. Changeux (1981) Dissection of the 66,000-dalton subunit of the acetylcholine receptor. Biochemistry 20: 2492-2497.

Yazulla, S. (1976) Cone input to bipolar cells in the turtle retina. Vision Res. 16: 737-744.

Yazulla, S., and J. Schmidt (1976) Radioautographic localization of ${ }^{125} \mathrm{I}-\alpha$-bungarotoxin binding sites in the retinas of the goldfish and turtle. Vision Res. 16: 878-880.

Zucker, C., and S. Yazulla (1982) Localization of synaptic and nonsynaptic nicotinic-acetylcholine receptors in the goldfish retina. J. Comp. Neurol. 204: 188-195. 